\title{
Bifurculapes Hitchcock 1858: a revision of the ichnogenus
}

\author{
PATRICK R. GETTY \\ Center for Integrative Geosciences, University of Connecticut, 354 Mansfield Road, Storrs, Connecticut 06269, USA \\ <patrick.getty@uconn.edu>
}

Date received: 20 August 2016 gate accepted: 16 November 2016

\begin{abstract}
Characters differentiating the arthropod trackway Bifurculapes from the similar ichnogenera Lithographus and Copeza include the position, arrangement and orientation of the tracks within the series. Of the five species of Bifurculapes originally described, only Bifurculapes laqueatus and Bifurculapes scolopendroideus are recognized herein; the other three ichnospecies are considered to be nomina dubia or junior subjective synonyms of Bifurculapes laqueatus. Two new specimens, recovered from the Early Jurassic East Berlin Formation of the Hartford Basin in Holyoke, Massachusetts, represent only the second unequivocal occurrence of the ichnogenus outside of the Deerfield Basin. Bifurculapes is currently known only from the Early Jurassic.
\end{abstract}

\section{RÉSUMÉ}

Les caractéristiques qui différencient la piste d'arthropode Bifurculapes des ichnogenres Lithographus et Copeza similaires sont la position, la disposition et l'orientation des traces à l'intérieur de la série. Parmi les cinq espèces de Bifurculapes originalement décrites, seules Bifurculapes laqueatus et Bifurculapes scolopendroideus sont ici reconnues. Les trois autres ichnoespèces sont considérées comme nomina dubia ou comme synonymes subjectifs plus récents de Bifurculapes laqueatus. Les deux nouveaux spécimens trouvés dans la formation du Jurassique précoce d'East Berlin dans le bassin de Hartford, à Holyoke, au Massachusetts, représentent seulement la seconde présence sans équivoque de l'ichnogenre à l'extérieur du bassin de Deerfield. À l'heure actuelle, Bifurculapes n'est associé qu'au Jurassique précoce.

[Traduit par la redaction]

\section{INTRODUCTION}

Edward Hitchcock was one of the most important nineteenth century pioneers of ichnology (Häntzschel 1975; Steinbock 1989; Pemberton et al. 2007). In a career that spanned nearly three decades, he devoted 11 papers and two books to the trace fossils of the early Mesozoic Hartford and Deerfield basins of Connecticut and Massachusetts (Lull 1953, p. 310). In these works, Hitchcock erected a bewildering array of 94 ichnogenera and 216 ichnospecies for both vertebrate and invertebrate traces (Rainforth 2005), only a few of which are in wide use today. The multitude of names proposed by Hitchcock is part of a larger phenomenon described by Häntzschel (1975, p. W24), who pointed out that the literature includes an excessive number of ichnotaxa, scattered among numerous publications.

The vast size of Hitchcock's ichnotaxonomic list is the result of at least two factors. First, in the absence of standardized nomenclatural rules in the nineteenth century, he discarded at will previously proposed names of some of his vertebrate ichnotaxa for new, objective synonyms that better fitted his changing view of trace fossil taxonomy (Olsen and Rainforth 2003; Rainforth 2005). Second, as an ichnological pioneer, he lacked standard criteria for establishing ichnotaxa, guidelines for which are only now being established (e.g., Demathieu and Demathieu 2002; Bertling et al. 2006; Minter et al. 2007). Following the ICZN (Ride et al. 1999), Rainforth (2005) addressed the issue of objective synonyms among Hitchcock's ichnotaxa, but the number of remaining taxa -71 ichnogenera and 185 ichnospecies - is still staggering. Various authors (e.g., Olsen et al. 1992; Keighley and Pickerill 1998; Rainforth 2005; Minter and Braddy 2009) have suggested that the number of ichnotaxa could be further reduced by subjective synonymy using modern criteria for evaluating ichnotaxa.

The present study, which constitutes a revision of Hitchcock's ichnogenus Bifurculapes, was stimulated by the discovery of two new specimens of this ichnogenus in Holyoke, Massachusetts (Fig. 1). Hitchcock established five ichnospecies within the ichnogenus: Bifurculapes curvatus Hitchcock 1865, Bifurculapes elachistotatus Hitchcock 1858, 

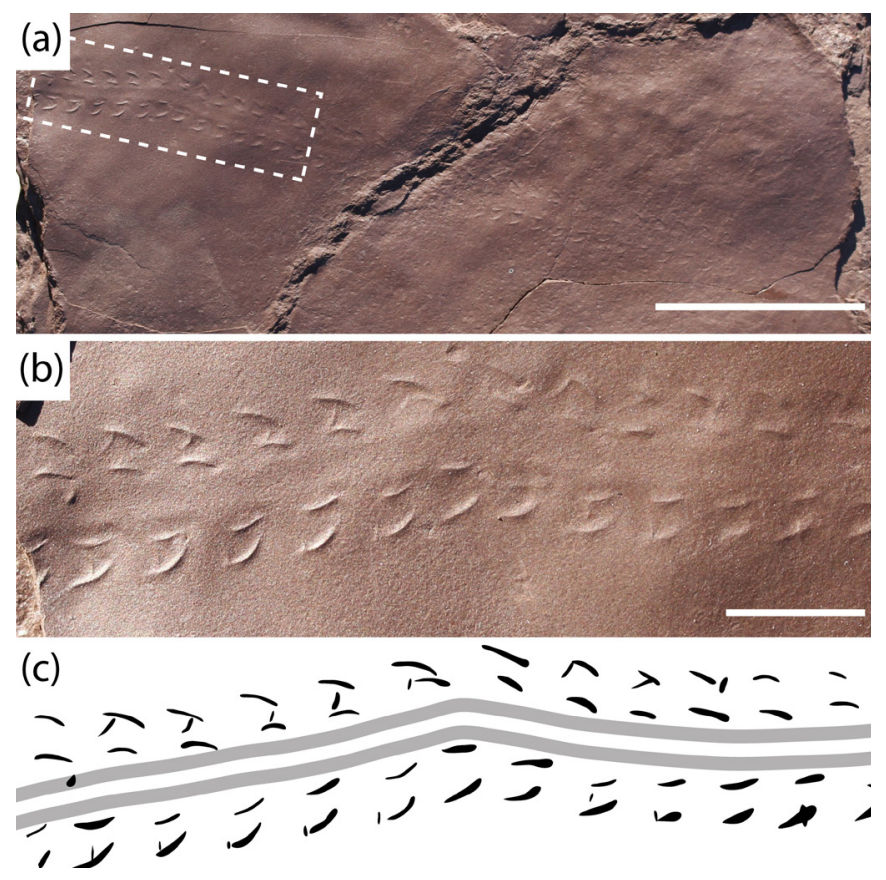

Figure 1. One of two newly discovered Bifurculapes laqueatus specimens from the Early Jurassic East Berlin Formation of Holyoke, Massachusetts. (a) Overview of the trackway, which is preserved as a natural cast on slab ACM.ICH 300. (b) Photograph and (c) interpretive drawing of the portion of the trackway surrounded by the box in (a). Note the abrupt change in trackway direction. Scale bars are $50 \mathrm{~mm}$ in (a) and $10 \mathrm{~mm}$ in (b).

Bifurculapes laqueatus Hitchcock 1858, Bifurculapes scolopendroideus Hitchcock 1858, and Bifurculapes tuberculatus Hitchcock 1858. The main focus of this study is to determine whether all of these ichnospecies can be distinguished, or if at least some can be considered subjective synonyms. Additionally, the ichnogeneric diagnosis is revised and tentative criteria for distinguishing Bifurculapes from Lithographus is provided. More work must be conducted on Hitchcock's other ichnogenera to evaluate further subjective synonymys. Also presented in this paper is a brief discussion of the stratigraphic and geographic distribution of the ichnogenus.

\section{GEOLOGICAL AND PALEONTOLOGICAL CONTEXT}

The specimens described herein were found in the Hartford and Deerfield basins of southern New England (Fig. 2). These basins are part of the Late Triassic to Early Jurassic Newark Supergroup of eastern North America, which formed as Pangea began to break up; they represent the rifting stage that presaged the opening of the Atlantic Ocean (Olsen 1978, 1997). The rate of crustal extension increased in the Early Jurassic, causing border faults on the eastern margin of the basins to coalesce and form asymmetrical, east-dipping half grabens (Schlische and

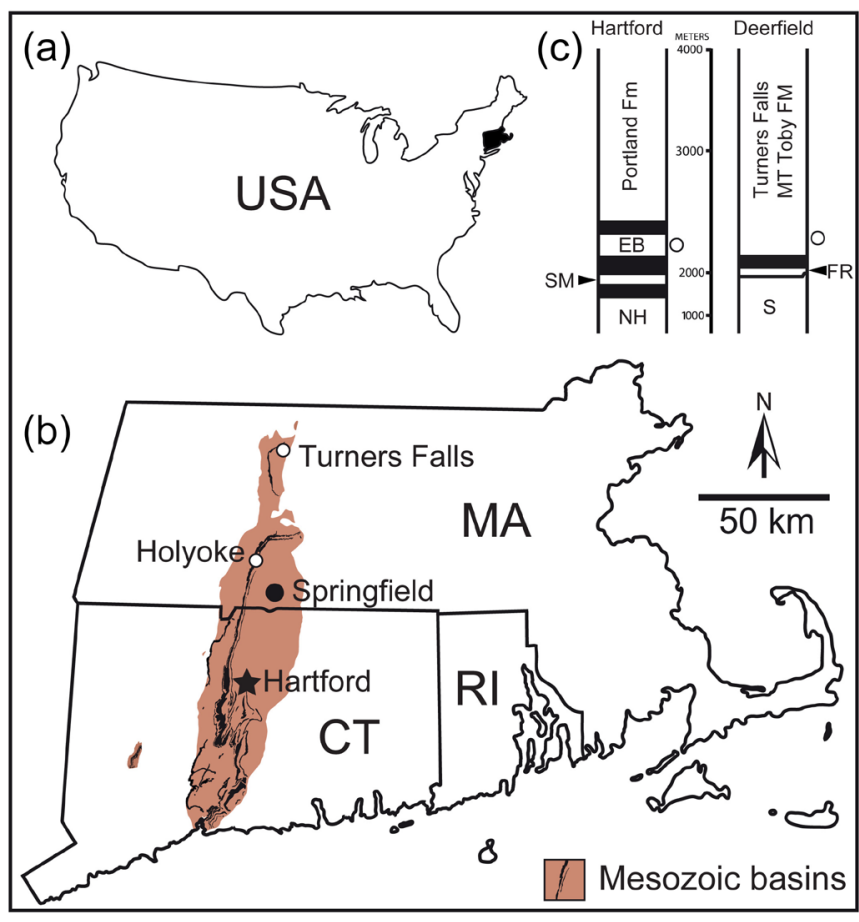

Figure 2. Geographical and geological context of Bifurculapes specimens described herein. (a) Sketch map of the contiguous United States with southern New England shaded black. (b) Map of southern New England states, Connecticut (CT), Massachusetts (MA), and Rhode Island (RI), showing the extent of the early Mesozoic basins and the locations from which Bifurculapes has been found. Sedimentary rocks are in light brown; igneous rocks are black. (c) Simplified stratigraphic columns of the Hartford and Deerfield basins showing the approximate positions of the fossil trackways. $\mathrm{EB}=$ East Berlin Formation, FR $=$ Fall River beds, $\mathrm{NH}=\mathrm{New}$ Haven Formation, $\mathrm{S}=$ Sugarloaf Formation, $\mathrm{SM}=$ Shuttle Meadow Formation.

Olsen 1990). The increased rate of sedimentation caused a change in deposition from fluvial to predominantly lacustrine. The lake deposits exhibit cycles of gray to black shale formed in deep, permanent bodies of water in alternation with red mudstone and sandstone formed in playas. Olsen (1986) attributed the cyclicity to Milankovich cycle-influenced climate changes. Deposition was interrupted during a $600 \mathrm{ka}$ interval by basaltic lava flows (Olsen et al. 1996). Models indicate that the paleoclimate was monsoonal (Parrish 1993), with a long dry season (Hubert 1978).

The material that Hitchcock collected came from lacustrine beds of the Early Jurassic Turners Falls Formation in the Deerfield Basin. (Hitchcock 1858, 1865). In particular, the type specimens of Bifurculapes laqueatus and Bifurculapes tuberculatus were found at Roswell Field's farm, Bifurculapes curvatus and Bifurculapes elachistotatus were found at the Lily Pond, and Bifurculapes scolopendroideus 
was found below the cataract in the Connecticut River. As noted by Lull (1953) and Olsen et al. (1992), both Field's Farm and the Lily Pond were among the most important of Hitchcock's collecting sites, each yielding large numbers of well-defined vertebrate and invertebrate traces.

The Holyoke, Massachusetts, specimens are from the Hartford Basin and were collected from a privately owned site located at $42^{\circ} 11^{\prime} 51.74^{\prime \prime} \mathrm{N}, 72^{\circ} 38^{\prime} 41.16^{\prime \prime} \mathrm{W}$. Nearly two meters of red mudstone and fine-grained sandstone of the Early Jurassic East Berlin Formation are exposed there. Oscillation ripples and mud cracks indicate deposition under playa conditions (Drzewiecki and Zuidema 2007), and sinuous mud cracks on one bed suggest incipient soil formation (Demicco and Gierlowski-Kordesch 1986; Gierlowski-Kordesch and Rust 1994). Vertebrate trace fossils include the theropod tracks Anchisauripus isp., Grallator isp., and Eubrontes giganteus, and the ornithischian track Anomoepus lactertoideus (Dalman and Weems 2013; Getty and Fox 2015). Invertebrate tracks, trails and burrows include Acanthichnus alternans, Helminthoidichnites tenuis, Planolites isp., Skolithos isp. and Treptichnus bifurcus (Getty and Fox 2015, fig. 2; Getty et al. 2016). An arthropod resting trace, assigned to the new ichnogenus Cheliceratichnus, was possibly made by a sun-spider-like animal (Dalman and Lucas 2015).

\section{MATERIALS AND METHODS}

The 54 trackways examined for this study are housed at the Beneski Museum of Natural History at Amherst College, the Peabody Museum of Natural History at Yale University, and the Science Museum in Springfield, Massachusetts. The abbreviations for these institutions are ACM, YPM and SSM respectively. The acronyms ICH, following ACM, and IP following YPM indicate that the specimens are part of the ichnology collection at the Beneski and the invertebrate paleontology collection at the Peabody. Each specimen was photographed under low-angled light, and measurements were taken from the photographs using the public-domain image-processing and analysis program ImageJ (Rasband 1997-2014). The measurements (Fig. 3) include track length, track width, angle to midline for the track, repeat distance between tracks, inner trackway width, and outer trackway width. Track length is defined herein as a straight line between the anterior and posterior tips of the tracks, whereas width is defined herein as the distance, perpendicular to length, from the line drawn between the tips of the track to the lateralmost point of curvature of the track. Inner and outer trackway widths were recorded from the most medial portion of the tracks in order to avoid spurious values resulting from variations in the angle to the trackway midline. Angles to midline were assigned positive values if the track was oriented posterolaterally and negative values if the track was oriented posteromedially. Morphometric analyses using track length and width were conducted to determine the uniqueness of the various

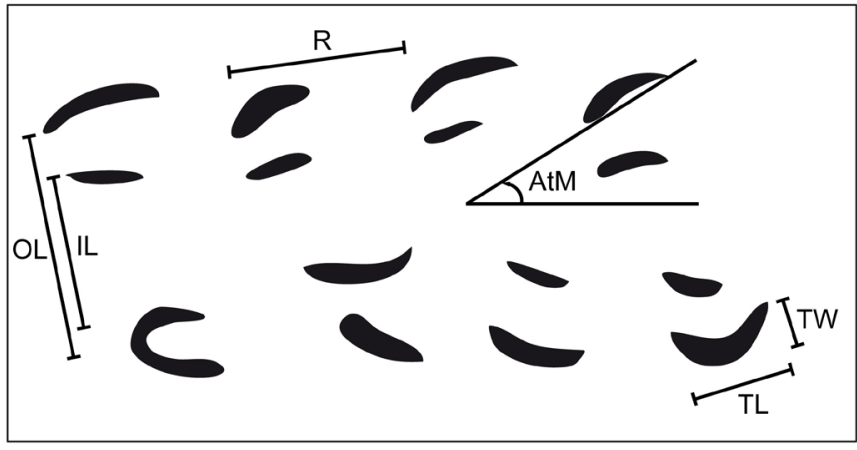

Figure 3. Trackway measurements employed in this study. AtM $=$ angle to midline, $\mathrm{IL}=$ inner trackway length, $\mathrm{OL}=$ outer trackway length, $\mathrm{R}=$ repeat distance (i.e., stride), $\mathrm{TL}$ $=$ track length, and TW $=$ track width.

ichnospecies relative to one another.

The systematic ichnology section below is guided by principles for dealing with the taxonomy of arthropod trackways as outlined by Bertling et al. (2006) and Minter et al. (2007). For example, undertracks and other poorly defined traces are unsuitable to serve as type specimens and are thus considered as nomena dubia (Bertling et al. 2006, p. 270). Additionally, synonymization is justified for intergrading specimens when the different morphologies represent minor variations within an ethological category, but not when the change in morphology results from changes in behavior that would be considered as different ethological categories (Minter et al. 2007, p. 369).

\section{SYSTEMATIC ICHNOLOGY}

\section{Ichnogenus Bifurculapes Hitchcock 1858}

(Figs. 1, 4)

1858 Bifurculapes; E, Hitchcock, p. 152.

1865 Biferculipes; E. Hitchcock, p. 14

(incorrect subsequent spelling).

1865 Bifurculipes; E. Hitchcock, p. 15, 16, plate 7, figs. 2 and 9 (incorrect subsequent spelling).

1865 Bifurcalipes; E. Hitchcock, plate 7, figs. 7 and 8 (incorrect subsequent spelling).

1871 Bifurculipes; C.H. Hitchcock, p. 21 (incorrect subsequent spelling).

1889 Bifurculipes; C.H. Hitchcock, p. 119 (incorrect subsequent spelling).

1915 Bifurculapes; Lull, p. 58, fig. 2.

1953 Bifurculapes; Lull, p. 42, fig. 2.

1975 Bifurculapes; Häntzschel, p. W46, fig. 28.4.

2006 cf. Bifurculapes; Lucas et al., p. 130, fig. 3B. non 1992 Bifurculapes; Demathieu et al., p. 30, fig. 7.2. non 2006 Bifurculapes; Santi, p. 205-206, figs. 5 and 6. 
TYPE SPECIES: Bifurculapes laqueatus Hitchcock 1858, designated by Lull (1953, p. 42).

OTHER SPECIES: Bifurculapes scolopendroideus Hitchcock 1858.

EMENDED DIAGNOSIS: A trackway consisting of two rows of elongate, straight or crescentic imprints arranged in series of two, or rarely, three tracks. Within series, the anterior tips of the two larger tracks form a line nearly perpendicular to the trackway midline. Series are arranged in staggered or alternate symmetry. Tracks are of different lengths, with the longest and intermediate length tracks oriented posterolaterally to the trackway axis and often divergent from each other, the smallest track is oriented oblique or perpendicular to the axis. The longest track is almost always on the outside of the trackway, with the middle length track on the inside and the smallest track between the other two.

REMARKS: Bifurculapes resembles other ichnogenera erected by Hitchcock, including Acanthichnus, Conopsoides, Copeza, Grammepus, Hamipes, Harpagopus, Harpepus, Lithographus, Sagittarius and Stratipes (Minter and Braddy 2009). However, most of these ichnogenera are also in need of revision, which is beyond the scope of this paper; consequently, except for Lithographus and Copeza, their relationships to Bifurculapes will be discussed elsewhere. Copeza with Lithographus was revised by Minter and Braddy (2009) based on a large number of specimens found in the Permian Robledo Mountains Formation of New Mexico.

Bifurculapes, Lithographus and Copeza can be differentiated from each other by the relative position of the three different tracks within the series and the orientation of the different tracks relative to the trackway midline. In Bifurculapes, the outer and inner tracks are nearly parallel to each other and are oblique or parallel to the trackway axis. By contrast, in Copeza the outer track is oriented parallel to the trackway midline and the inner track is perpendicular to the trackway midline. In Lithographus, the outer track tends to be perpendicular to the trackway midline, whereas the inner or middle track is parallel to the trackway midline (Minter and Braddy 2009; Minter et al. 2012).

Further, Bifurculapes and Lithographus can be differentiated by the relative position and orientation of the different tracks, as defined by their length. In Lithographus the longest track is the middle or inner track (Minter and Braddy 2009; Minter et al. 2012), whereas in Bifurculapes the longest track is on the outside of the trackway. In Lithographus, the mid-sized track is oriented perpendicular to the trackway midline, whereas in Bifurculapes it is oriented posterolaterally or posteromedially. The smallest track is oriented anterolaterally or parallel to the trackway midline in Lithographus, but perpendicular to the trackway axis in Bifurculapes. Finally, in Bifurculapes, the two longer tracks are located nearly laterally with respect to each other, whereas in Lithographus there are distinct anterior, middle, and posterior tracks.
The preservation of medial drags in some specimens, including ACM.ICH 300, indicates that the differences between these two ichnogenera do not result from undertracking (in contrast to the views of Lucas et al. 2006 and Minter and Braddy 2009), because these features are the first parts of arthropod trackways lost as a result of undertracking and similar phenomena (e.g., Goldring and Seilacher, 1971; Getty et al. 2013).

Hitchcock (1858, 1865) erected five ichnospecies of Bifurculapes: Bifurculapes curvatus, Bifurculapes elachistotatus, Bifurculapes laqueatus, Bifurculapes scolopendroideus and Bifurculapes tuberculatus (Fig. 4). Subsequently, Lull (1953) designated Bifurculapes laqueatus as the type species, and thus it has priority in synonymies. Herein, Bifurculapes curvatus and Bifurculapes elachstotatus are considered to be junior subjective synonyms of Bifurculapes laqueatus because their morphologies overlap or intergrade with that of the type ichnospecies. Hitchcock (1865) erected Bifurculapes curvatus for specimens in which the tracks were supposedly more curved than in other species. A comparison of Bifurculapes laqueatus and Bifurculapes curvatus tracks, however, indicates that the difference in track curvature between the two species is negligible (Fig. 5). Bifurculapes elachstotatus was differentiated from other species in that its tracks were much shorter and did not touch. Some specimens, however, show that track length varies along the course of individual trackways. For example, both YPM IP 160381 and ACM.ICH 55/62 have sections that would be attributed to Bifurculapes laqueatus or Bifurculapes elachistotatus if found separately.

In 1865, Hitchcock removed Bifurculapes tuberculatus from the ichnogenus, arguing that the specimens on which the species was based were eroded remnants of more complete trackways. The lectotype of Bifurculapes tuberculatus, on ACM.ICH 36/19 (Fig. 4i), supports Hitchcock's contention that the ichnospecies is in fact a preservational variant of a more complete trace. The trackway is preserved on two separate laminae; only the distal tips of the tracks are impressed on the overlying lamina, whereas complete tracks are preserved on the underlying lamina. Thus the punctate marks in portions of the lectotype are incomplete overprints. In addition to ACM.ICH36/19, Hitchcock (1858) listed three other slabs on which Bifurculapes tuberculatus was supposedly impressed: ACM.ICH 36/45, 36/46, and 36/47. The species cannot be found, however, on any of these slabs, and Hitchcock (1865) actually identified the trackway on $36 / 47$ as belonging to his new ichnogenus Pterichnus. Considering that the lectotype of Bifurculapes tuberculatus is a taphonomic variant of a more complete trackway, and that other examples cannot be found on the slabs that represent the type series, this ichnospecies is herein considered to be a nomen dubium. 


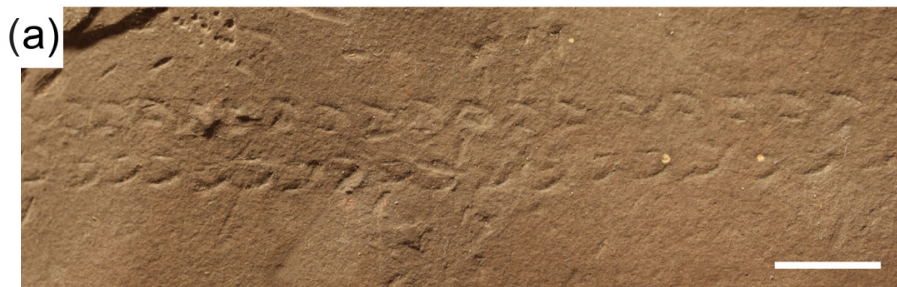

(b)
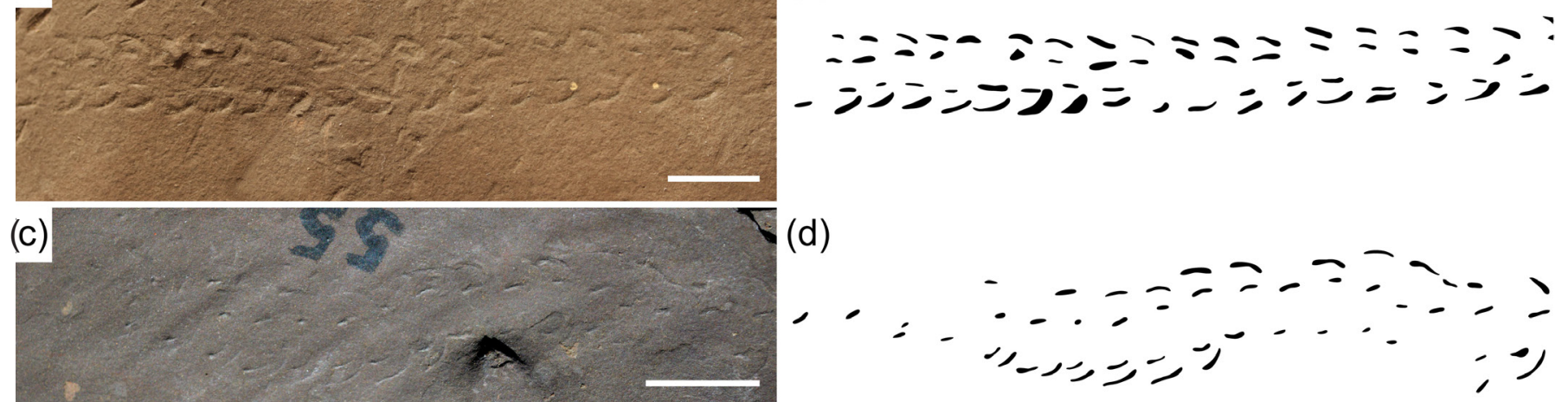

(e)

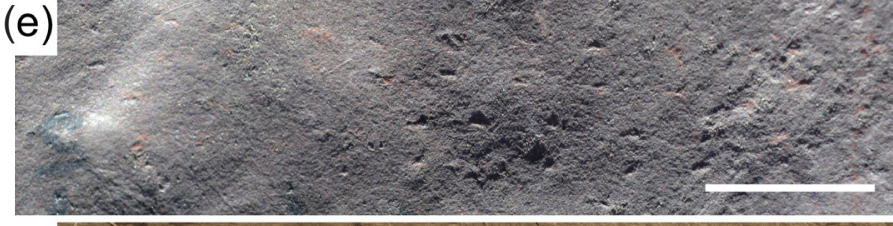

(g)

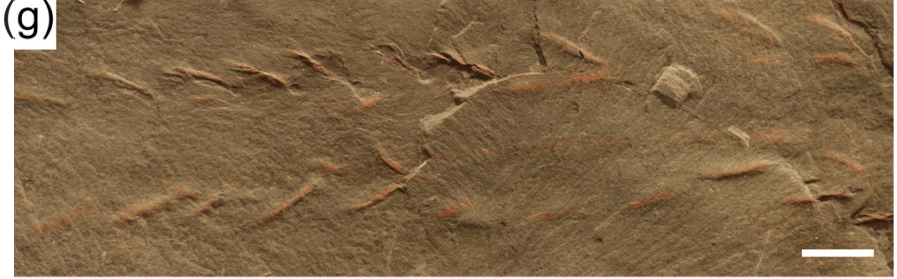

(i)

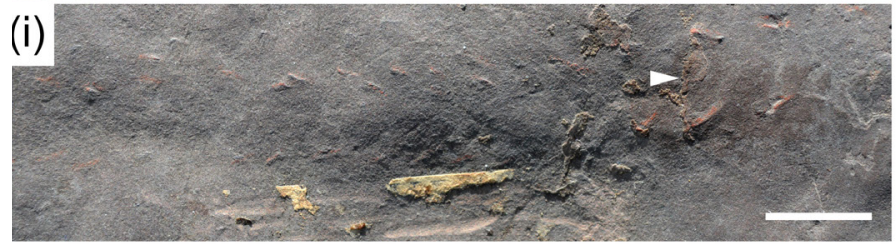

(d)

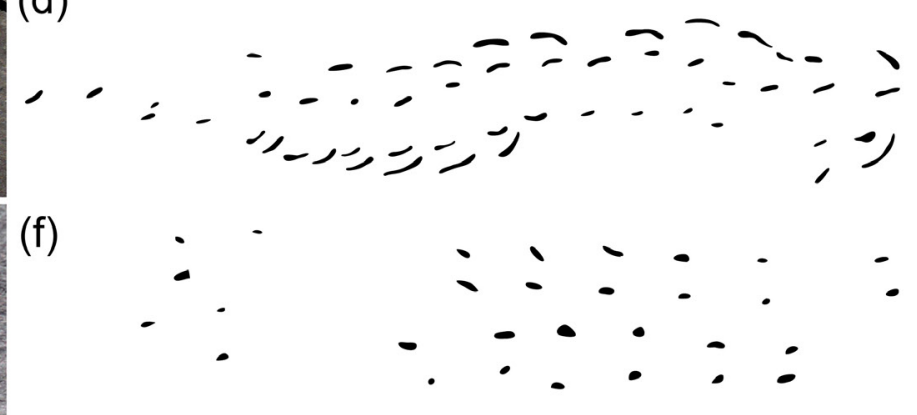

(h)

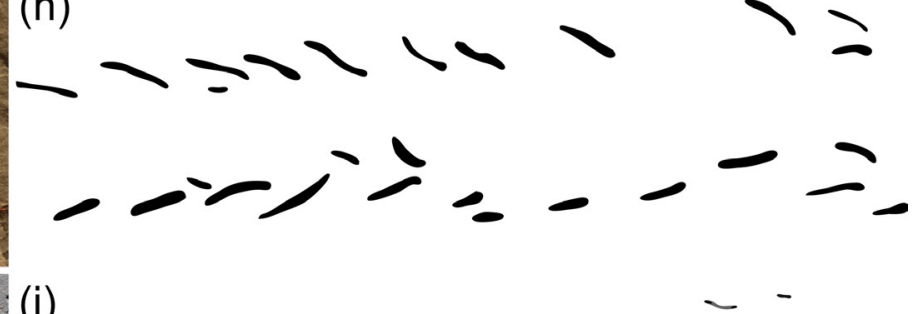

(j)

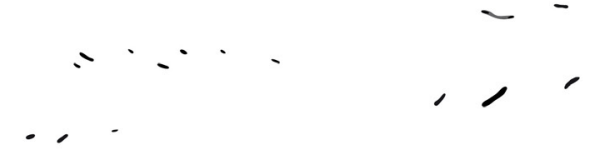

Figure 4. Lectotypes of the five ichnospecies of Bifurculapes established by Edward Hitchcock, with interpretive line drawings. (a, b) Bifurculapes laqueatus on ACM.ICH 36/33. (c, d) Bifurculapes curvatus on ACM.ICH 55/62. (e, f) Bifurculapes elachistotatus on ACM.ICH 36/17. (g, h) Bifurculapes scolopendroideus on ACM.ICH 36/14. (i, j) Bifurculapes tuberculatus on ACM.ICH 36/19. All scale bars are $10 \mathrm{~mm}$.

\section{Bifurculapes laqueatus Hitchcock 1858}

(Figs. 1, 4a-f)

1858 Bifurculapes laqueatus E, Hitchcock, p. 153.

1865 Biferculipes laqueatus; E. Hitchcock, p. 16.

1865 Bifurculipes curvatus; E. Hitchcock, p. 15, plate 7, figs. 2 and 9.

1865 Biferculipes elachistotatus; E. Hitchcock, p. 16.

1889 Bifurculipes laqueatus; C.H. Hitchcock, p. 119.

1889 Bifurculipes curvatus; C.H. Hitchcock, p. 119.

1889 Bifurculipes elachistotatus; C.H. Hitchcock, p. 119.

1915 Bifurculapes laqueatus; Lull, p. 58, fig. 2.

1915 Bifurculapes curvatus; Lull, p. 58.

1915 Bifurculapes elachistotatus; Lull, p. 58.

1953 Bifurculapes laqueatus; Lull, p. 42, fig. 2.

1953 Bifurculapes curvatus; Lull, p. 42.

1953 Bifurculapes elachistotatus; Lull, p. 42.

2006 cf. Bifurculapes ichnosp.; Lucas et al., p. 130, fig. 3B.
OCCURRENCE: Early Jurassic (Hettangian), Turners Falls Formation of the Deerfield Basin, East Berlin Formation of the Hartford Basin, and Moenave Formation of the Zuni sag.

EMENDED DIAGNOSIS: Bifurculapes with two to three tracks per series and a regularly repeating, alternate trackway pattern.

DESCRIPTION: Trackways of this species have external widths from 0.4 to $0.9 \mathrm{~cm}$, and internal widths of 0.1 to 0.5 $\mathrm{cm}$. The tracks are arranged into staggered to alternating series of two to three, and overlap between sets is rare. The position of the third track, where present, is variable, even within a single trackway. It may be positioned anterior or posterior to the other two tracks, or anywhere between; in a lateral direction, this track may occur close to the trackway midline or between the other two. Individual tracks may be straight or curved. Outer track lengths range from 0.5 to $5.4 \mathrm{~mm}$, and inner track lengths are from 0.4 to $4.3 \mathrm{~mm}$. Outer tracks are typically oriented posterolaterally, with angles to midline ranging from $0^{\circ}$ to $55^{\circ}$, whereas 


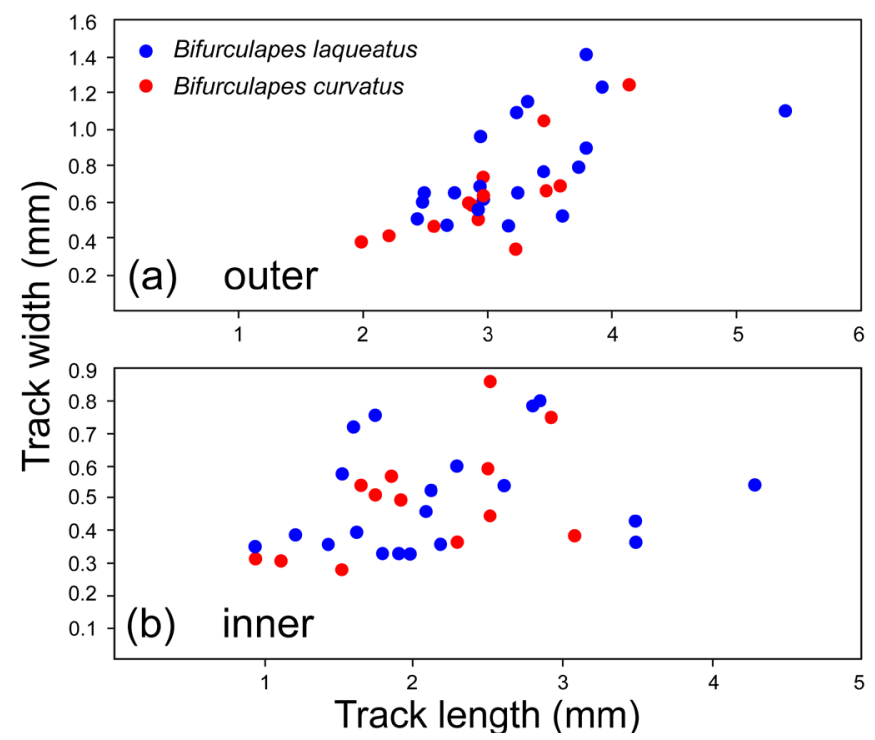

Figure 5. X-Y scatter plot of track length and width for the ichnospecies Bifurculapes laqueatus and Bifurculapes curvatus. (a) Measurements for outer tracks.

(b) Measurements for inner tracks.

inner tracks are oriented posterolaterally, posteromedially, or parallel to the trackway midline, with angles ranging from $-37^{\circ}$ to $32^{\circ}$. The repeat distance, or stride, ranges from 0.2 to $0.7 \mathrm{~cm}$. Medial drags are rarely present.

REMARKS: As noted previously, the ichnospecies concept for Bifurculapes laqueatus is expanded from Hitchcock's (1858) original understanding to include morphologies that he had included in Bifurculapes curvatus and Bifurculapes elachistotatus because of intergradation among the ichnospecies. Bifurculapes laqueatus is retained as the senior synonym because it was designated the type species by Lull (1953).

\section{Bifurculapes scolopendroideus Hitchcock 1858}

(Fig. 4g-h)

1858 Bifurculapes scolopendroideus E, Hitchcock, p. 153.

1865 Biferculipes scolopendroideus; E. Hitchcock, p. 16.

1889 Bifurculipes scolopendroideus; C.H. Hitchcock, p. 119.

1915 Bifurculapes scolopendroideus; Lull, p. 58.

1953 Bifurculapes scolopendroideus; Lull, p. 43.

OCCURRENCE: Early Jurassic (Hettangian), Turners Falls Formation of the Deerfield Basin.

EMENDED DIAGNOSIS: Bifurculapes with one to two tracks per series; the inner tracks are only intermittently present. Where present, the inner tracks are oriented either parallel to or inward relative to the trackway midline, and are more irregularly placed than in Bifurculapes laqueatus such that the paired series are not always visible.

DESCRIPTION: Trackways assigned to this species have external widths of 1.6 and $2.7 \mathrm{~cm}$, and internal widths of 1.4 and $1.5 \mathrm{~cm}$. Outer track lengths range from 0.6 to 1.3 $\mathrm{cm}$, and inner track lengths from 0.3 to $0.7 \mathrm{~cm}$. The angle to midline for the outer track ranges from 13 to $39^{\circ}$, that of the inner tracks is 0 to $48^{\circ}$. The stride of the outer tracks is variable within each trackway, from 0.7 to $2.0 \mathrm{~cm}$ in $36 / 14$ and 0.7 to $2.0 \mathrm{~cm}$ in $36 / 41$. The short stride length causes overlap, up to $0.3 \mathrm{~cm}$, between some of the tracks in 36/14. Inner tracks are placed medial to, or in line with, the outer tracks relative to the trackway midline, and in some cases are located nearly midway between the outer tracks so that series are not discernable. The close spacing of some of the outer tracks, coupled with the positioning of the inner tracks, sometimes gives the impression of a single, bifurcated trace.

REMARKS: Lull (1953) noted that Bifurculapes scolopendriodeus exhibits a morphology unlike that of other ichnospecies of Bifurculapes in that the inner tracks are not always present, but when they occur they are parallel to the trackway axis. Re-examination of the lectotype confirms Lull's observations: of ten track series on the left side of the trackway that are unequivocally associated with the trace, only two exhibit two tracks. On the right side of the trackway only three, or possibly four, of eleven track series exhibit two tracks. However, the trackway appears to be an undertrack, which might explain the loss of some of the inner tracks. Lull (1953) was skeptical of including Bifurculapes scolopendroideus within the ichnogenus but ultimately did not remove it. I share Lull's skepticism but retain its present assignment pending the collection of better specimens.

\section{DISCUSSION \\ Geographic and stratigraphic distribution}

Outside of the Hartford and Deerfield basins, tentative occurrences of Bifurculapes have been recorded from the Permian of France and Italy (Demathieu et al. 1992; Durand 2001; Santi 2006), the Triassic of Argentina (Melchor 2004), the Jurassic of Utah (Lucas et al. 2006; Milner et al. 2009), and the Cretaceous of Alaska (Fiorillo et al. 2009). Many of these trackways, however, are unlike the specimens described by Hitchcock $(1858,1865)$ and can be assigned to other ichnotaxa, or were not figured. For example, Melchor (2004) and Fiorillo et al. (2009) did not figure the specimens that they reported; furthermore, Fiorillo et al. were uncertain of the ichnogeneric assignment of the trackways. Additionally, Santi (2006) illustrated trackways that were similar to those reported by Demathieu et al. (1992) and Durand (2001). Based on Santi's figure, the trackways appear to have as many as four tracks per series, which would preclude them from inclusion in Bifurculapes. As Santi (2006) noted, they might belong to Secundichnium alternans, which was erected by Walter (1983). The specimen illustrated by Lucas et al. (2006) resembles specimen ACM ICH 55/90 that Hitchcock (1865) attributed to Bifurculapes curvatus. Thus, the Utah specimen appears to be the first unequivocal occurrence of 
the ichnogenus outside of the Deerfield Basin. Therefore, the specimens from Holyoke, Massachusetts, constitute the second undoubted occurrence of Bifurculapes outside of the type region. These three undoubted occurrences of Bifurculapes are all of Early Jurassic age.

\section{Trackmaker}

When Hitchcock (1858) first described Bifurculapes, he proposed that the likely trackmakers were either arthropods or crustaceans, but he later (1865) considered the fossils to be insect traces. Lull $(1915,1953)$ concurred with Hitchcock's final assessment and considered insects to be the most likely trackmakers. Most subsequent researchers (e.g., Mayoral 2001) have also suggested that the ichnogenus resulted from insect activity, although Demathieu et al. (1992) argued that a triopsid crustacean was a more likely trackmaker for possible specimens from France.

Eiseman and Charney (2010, p. 501) have figured darkling beetle (Coleoptera: Tenebrionidae) trackways that are similar to Bifurculapes laqueatus in that the track series sometimes consists of two elongate and posteriorlyoriented tracks, but differ in that the longer track is positioned medially. Overall, however, these modern beetle trackways support the inference that Bifurculapes laqueatus was indeed made by an insect. Bifurculapes scolopendroideus, on the other hand, is larger and more irregular than Bifurculapes laqueatus, and it also occurs in dark grey, lacustrine shale. This latter observation supports the possibility that Bifurculapes scolopendroideus may be the trace of a crustacean.

\section{CONCLUSIONS}

The ichnogenus Bifurculapes, which represents trackways made by insects, is revised. In addition to the type species, Bifurculapes laqueatus, only the ichnospecies Bifurculapes scolopendroideus is recognized herein. Three other ichnospecies, Bifurculapes curvatus, Bifurculapes elachistotatus and Bifurculapes tuberculatus, are considered nomina dubia or junior subjective synonyms of Bifurculapes laqueatus. Characters differentiating Bifurculapes from Lithographus and Copeza include the position, arrangement, and orientation of the tracks within the series. For example, the outer and inner tracks in Bifurculapes are nearly parallel to each other and are oblique or parallel to the trackway midline, whereas in Lithographus the inner or middle track is parallel to the midline and the outer track is perpendicular to the midline. In Copeza, the inner track is perpendicular to the trackway midline and the outer parallel to the midline. Further, in Bifurculapes the largest track is on the outside of the track series, whereas in Lithographus it is the middle or inner track. Additionally, in Bifurculapes the two larger tracks are lateral to each other, whereas in Lithographus the largest track is behind the middle-sized one. Two new specimens, recovered from the Early Jurassic East Berlin Formation of the Hartford Basin in Holyoke, Massachusetts, represent only the second unequivocal occurrence of the ichnogenus outside of the Deerfield Basin, with the first being from the Jurassic of Utah. Currently, the ichnogenus is known only from the Early Jurassic.

\section{ACKNOWLEDGMENTS}

I thank Sebastian Dalman for bringing the Gary Gaulin Dinosaur Track Site to my attention, and Gary and Laurie Gaulin for granting me permission to study the fossils on their property. I also acknowledge the keen eye of Robert Sproule for finding the Bifurculapes laqueatus illustrated in Fig 1. I appreciate the hospitality of Susan Butts, of the Peabody Museum, and Kate Wellspring, formerly of the Beneski Museum of Natural History, during my examination of the specimens in their care. I also thank Richard Sanderson and David Stier of the Springfield Science Museum for accessioning a second Bifurculapes laqueatus specimen from Holyoke (SSM 2016/11-4) into their collections. This paper benefited from thorough reviews by Nicholas Minter and Andrew Rindsberg.

\section{REFERENCES}

Bertling, M., Braddy, S.J., Bromley, R.G., Demathieu, G.R., Genise, J., Mikuláš, R., Nielsen, J.K., Nielsen, S.S., Rindsberg, A.K., Schlirf, M., and Uchman, A. 2006. Names for trace fossils: a uniform approach. Lethaia, 39, pp. 265-286. https://doi. org/10.1080/00241160600787890

Dalman, S.G. and Lucas, S.G. 2015. Lower Jurassic arthropod resting trace from the Hartford Basin of Massachusetts, USA. Ichnos, 22, pp. 177-182. https:// doi.org/10.1080/10420940.2015.1059337

Dalman, S.G. and Weems, W.E. 2013. A new look at morphological variation in the ichnogenus Anomoepus, with special reference to material from the Lower Jurassic Newark Supergroup: implications for ichnotaxonomy and ichnodiversity. Bulletin of the Peabody Museum of Natural History, 54, pp. 67-124. https://doi.org/10.3374/014.054.0104

Demathieu, G. and Demathieu, P. 2002. Concerning the erection of ichnogenera and ichnospecies in vertebrate ichnotaxonomy. Ichnos, 9, pp. 117-121. https://doi. org/10.1080/10420940216424

Demathieu, G., Gand, G., and Toutin Morin, N. 1992. La palichnofaune des bassin permiens provencaux. Geobios, 25, pp. 19-54. https://doi.org/10.1016/S00166995(09)90036-5

Demicco, R.V. and Gierlowski-Kordesch, E. 1986. Facies sequences of a semi-arid closed basin: the Lower Jurassic East Berlin Formation of the Hartford Basin, 
New England, U.S.A. Sedimentology, 33, pp. 107-118.

Drzewiecki, P.A. and Zuidema, S. 2007. Sequence stratigraphy of playa and perennial lake deposits, Jurassic East Berlin Formation, central Connecticut. Northeastern Geology and Environmental Sciences, 29, pp. 49-68.

Durand, M. 2001. The continental Permian-Triassic series of Provence (southeast France). In Field trip guidebook, international field conference on the stratigraphic and structural evolution of the Late Carboniferous to Triassic continental and marine successions in Tuscany (Italy). Regional Reports and general correlations. 30 April-7 May 2001 Siena (Italy). 29 p.

Eiseman, C. and Charney, N. 2010. Tracks \& sign of insects and other invertebrates: a guide to North American species. Stackpole Books, Mechanicsburg. 582 p.

Fiorillo, A.R., Hasiotis, S.T., Kobayashi, Y., and Tomsich, C.S. 2009. A pterosaur track from the Denali National Park, Alaska Range, Alaska, United States. Palaios, 24, pp. 466-472. https://doi.org/10.2110/palo.2008.p08-129r

Getty, P.R. and Fox, N. 2015. An isolated Eubrontes giganteus trackway from the Gary Gaulin Dinosaur Track Site (Early Jurassic, East Berlin Formation), Holyoke, Massachusetts. Northeastern Geoscience, 33, pp. 16-21.

Getty, P.R., Sproule, R, Wagner, D., and Bush, A.M. 2013. Variation in wingless insect trace fossils: insights from neoichnology and the Pennsylvanian of Massachusetts. Palaios, 28, pp. 243-258. https://doi.org/10.2110/ palo.2012.p12-108r

Getty, P.R., McCarthy, T.D., Hsieh, Shannon, and Bush, A.M. 2016. A new reconstruction of continental Treptichnus based on exceptionally preserved material from the Jurassic of Massachusetts. Journal of Paleontology, 90, pp. 269-278. https://doi.org/10.1017/jpa.2016.20

Gierlowski-Kordesch, E. and Rust, B.R. 1994. The Jurassic East Berlin Formation, Hartford Basin, Newark Supergroup (Connecticut and Massachusetts): a saline lake-playa-alluvial plain system. In Sedimentology and geochemistry of modern and ancient saline lakes. Edited by R.W. Renaut and W.M. Last. Society for Sedimentary Geology, Tulsa, Oklahoma, pp. 249-265. https://doi.org/10.2110/pec.94.50.0249

Goldring, R. and Seilacher, A. 1971. Limulid undertracks and their sedimentological implications. Neues Jahrbuch fur Paläontologie und Geologie Abhandlungen, 137, pp. 422-442.

Häntzschel, W. 1975. Trace fossils and problematica. In Treatise on invertebrate paleontology, part W. Miscellanea, supplement I. Edited by C. Teichert. Geological Society of America and University of Kansas Press. 269 p.

Hitchcock, C.H. 1871. Account and complete list of the Ichnozoa of the Connecticut valley. In Official topographical atlas of Massachusetts. Edited by F.H. Walling and O.W. Gray, pp. 20-21.
Hitchcock, C.H. 1889. Recent progress in ichnology. Proceedings of the Boston Society of Natural History, 24, pp. 117-127.

Hitchcock, E. 1858. Ichnology of New England. A report on the sandstone of the Connecticut Valley, especially its fossil footmarks. William White, Boston. 220 p.

Hitchcock, E. 1865. Supplement to the ichnology of New England. A report to the Government of Massachusetts, in 1863. Wright and Potter, Boston. $96 \mathrm{p}$.

Hubert, J.F. 1978. Paleosol caliche in the New Haven arkose, Newark Group, Connecticut. Paleogeography, Palaeoclimatology, Palaeoecology, 24, pp. 151-168. https://doi.org/10.1016/0031-0182(78)90004-4

Keighley, D.G. and Pickerill, R.K. 1998. Systematic ichnology of the Mabou and Cumberland groups (Carboniferous) of western Cape Breton Island, eastern Canada, 2: surface markings. Atlantic Geology, 34, pp. 83-112. https://doi.org/10.4138/2041

Lucas, S.G. Lerner, A.J., Milner, A.J., and Lockley, M.G. 2006. Lower Jurassic invertebrate ichnofossils from a clastic lake margin, Johnson Farm, southwestern Utah. In The Triassic-Jurassic terrestrial transition. Edited by J.D. Harris, S.G. Lucas, J.A. Speilmann, M.G. Lockley, A.R.C. Milner, and J.I. Kirkland. New Mexico Museum of Natural History and Science Bulletin 37, pp. 128-136.

Lull, R.S. 1915. Triassic life of the Connecticut Valley. State of Connecticut, State Geological and Natural History Survey Bulletin 24. 285 p. https://doi.org/10.5962/bhl. title. 70405

Lull, R.S. 1953. Triassic life of the Connecticut Valley, revised. State of Connecticut, State Geological and Natural History Survey Bulletin 81. 336 p.

Mayoral, E. 2001. Pistas fósiles de artrópodos. Boletín de la Sociedad Entomológica Aragonesa, 28, pp. 15-33.

Melchor, R.N. 2004. Trace fossil distribution in lacustrine deltas: examples from the Triassic rift lakes of the Ischigualasto-Villa Unión basin, Argentina. In The application of ichnology to palaeoenvironmental and stratigraphic analysis. Edited by D. McIlroy. Geological Society, London, Special Publication 228, pp. 335-354. https://doi.org/10.1144/gsl.sp.2004.228.01.15

Milner, A.R.C., Harris, J.D., Lockley, M.G., Kirkland, J.I., and Matthews, N.A. 2009. Bird-like anatomy, posture, and behavior revealed by an Early Jurassic theropod dinosaur resting trace. PLoS ONE 4: e4591. https://doi. org/10.1371/journal.pone.0004591

Minter, N.J. and Braddy, S.J. 2009. Ichnology of an Early Permian intertidal flat: the Robledo Mountains Formation of southern New Mexico, USA. Special Papers in Palaeontology, 82, pp. 5-107.

Minter, N.J., Braddy, S.J., and Davis, R.B. 2007. Between a rock and a hard place: arthropod trackways and ichnotaxonomy. Lethaia, 40, pp. 365-375. https://doi. org/10.1111/j.1502-3931.2007.00035.x

Minter, N.J., Lockley, M.G., Hun, M., Hwang, K.-G., and Kim, J.Y. 2012. Lithographus, an abundant arthropod 
trackway from the Cretaceous Haenam Tracksite of Korea. Ichnos, 19, pp. 115-120. https://doi.org/10.1080 /10420940.2011.625756

Olsen, P.E. 1978. On the use of the term Newark for Triassic and Early Jurassic rocks of eastern North America. Newsletters on Stratigraphy, 7, pp. 90-95. https://doi. org/10.1127/nos/7/1978/90

Olsen, P.E. 1986. A 40-million-year lake record of early Mesozoic orbital climactic forcing. Science, 234, pp. 842-848. https://doi.org/10.1126/science.234.4778.842

Olsen, P.E. 1997. Stratigraphic record of the early Mesozoic breakup of Pangea in the Laurasia-Gondwana rift system. Annual Review of Earth and Planetary Sciences, 25, pp. 337-401. https://doi.org/10.1146/ annurev.earth.25.1.337

Olsen, P.E. and Rainforth, E.C. 2003. The Early Jurassic ornithischian dinosaurian ichnogenus Anomoepus. In The great rift valleys of Pangea in eastern North America, Volume 2: sedimentology, stratigraphy, and paleontology. Edited by P.M. LeTourneau and P.E. Olsen. Columbia University Press, New York, pp. 314367.

Olsen, P.E., McDonald, N.G., Huber, P, and Cornet, B. 1992. Stratigraphy and paleoecology of the Deerfield Rift Basin (Triassic-Jurassic, Newark Supergroup), Massachusetts. In Guidebook for field trips in the Connecticut Valley region of Massachusetts and adjacent states. Edited by P. Robinson and J.B Brady. New England Intercollegiate Geological Conference, pp. 488-535.

Olsen, P.E., Schlische, R.W., and Fedosh, M.S. 1996. 580 ky duration of the Early Jurassic flood basalt event in eastern North America estimated using Milankovitch cyclostratigraphy. In The Continental Jurassic. Edited by M. Morales. Museum of Northern Arizona Bulletin 60, pp. 11-22.

Parrish, J.T. 1993. Climate of the supercontinent Pangea. Journal of Geology, 101, pp. 215-233. https://doi. org/10.1086/648217
Pemberton, S.G., Gingras, M.K., and MacEachern, J.A. 2007. Edward Hitchcock and Roland Bird: two early titans of vertebrate ichnology in North America. In Trace fossils: concepts, problems, prospects. Edited by W. Miller III. Elsevier, Amsterdam, pp. 32-51. https:// doi.org/10.1016/B978-044452949-7/50129-7

Rainforth, E.C. 2005. Ichnotaxonomy of the fossil footprints of the Connecticut Valley (Early Jurassic, Newark Supergroup, Connecticut and Massachusetts). Unpublished Ph.D. thesis, Columbia University, New York, $1301 \mathrm{p}$.

Rasband, W.S. 1997-2014. Image): U.S. National Institutes of Health, Bethesda, Maryland, USA. URL <http:// imagej.nih.gov/ij/,> March 2015.

Ride, W.D.L., Cogger, H.G., Dupuis, C., Kraus, O., Minelli, A., Thompson, F.C., and Tubbs, P.K. 1999. International Code of Zoological Nomenclature Fourth Edition. The International Trust for Zoological Nomenclature: online (incorporating 2012 amendments). URL $<$ http://iczn.org/iczn/index.jsp>. March 2015.

Santi, G. 2006. Lower Permian invertebrate ichnocoenosis from the Orobic Basin, northern Italy. Bollettino della Società Paleontologica Italiana, 45, pp. 201-212.

Schlische, R.W. and Olsen, P.E. 1990. Quantitative filling model for continental extensional basins with applications to early Mesozoic rifts of eastern North America. The Journal of Geology, 98, pp. 135-155. https://doi.org/10.1086/629390

Steinbock, R.T. 1989. Ichnology of the Connecticut valley: a vignette of American science in the early nineteenth century. In Dinosaur tracks and traces. Edited by D.D. Gillette and M.G. Lockley. Cambridge University Press, New York, pp. 27-32.

Walter, H. 1983. Zur Taxonomie, Ökologie, und Biostratigraphie der Ichnia limnischterrestrischer Arthropoden des mitteleuropäischen Jungpaläozoikum. Freiberger Forschungsheft, C382, pp. 146-193.

Editorial responsibility: Robert A. Fensome 